\title{
THE EFFECT OF CONCEPT ORIENTED READING INSTRUCTION (CORI) STRATEGY TOWARD STUDENTS' READING COMPREHENSION
}

\author{
Umi Kalsum \\ Bambang Suwarno \\ I Wayan Dharmayana \\ English Post Graduate Study Program \\ The Faculty of Teacher and Training Education \\ University of Bengkulu \\ Email: umkagoan@gmail.com
}

\begin{abstract}
The purpose of this study is to find the effect of CORI (Concept-Oriented Reading Instruction)strategy on students' reading comprehension. This reseach was focused on whether CORI strategy affected students' reading comprehension. This research employed a quasi-experimental design. The subjects comprised 48 students of grade VIII of SMPN 4 Kota Bengkulu, divided into two classes, the experiment and control class. The instrument was a reading test. The result showed that CORI strategy was effective to improvestudents' reading comprehension. In addition, the students also had positive attitudes toward the use of CORI strategy. It is recommended to conduct an experiment for another school level.
\end{abstract}

Keywords: Reading comprehension, CORI strategy

ABSTRAK: Tujuan dari penelitian ini adalah untuk mengetahui pengaruh dari CORI (Concept-Oriented Reading Instruction) strategi terhadap pemahaman membaca siswa. Penelitian ini fokus pada apakah CORI strategi mempengaruhi pemahaman membaca siswa. Penelitian ini menggunakan quasi eksperiment. Subjek penelitian terdiri dari 48 siswa dari kelas VIII S MPN 4 kota Bengkulu. Subjek penelitian dibagi menjadi dua kelompok, kelompok eksperimen dan kelompok kontrol. Instrumen penelitian adalah tes bacaan. Hasil penelitian menunjukan bahwa CORI strategi berdampak dalam meningkatkanpemahaman membaca siswa. Selain itu siswa memberikan tanggapan positif terhadap penggunaan CORI strategi. Oleh sebab itu disarankan untuk melakukan penelitian pada level sekolah yang berbeda.

Kata Kunci: Pemahaman membaca, CORI strategi

\section{INTRODUCTION}

Reading is an important point for students to gain knowledge as many as possible. The level of knowledge of a person can be seen by how much he reads. Furthermore, the main purpose of reading is to make comprehension in getting meaning of the text and measure the extent of topics understanding. Thus, students will get more information from their reading activity.

Morever, comprehension is a developmental skill in discribing idea which is begun by the word level and proceeding to attach meaning to an entire reading selection (Kintsch, Rawson, Snowling, and Hulme, 2005). According to Seyed et al (2010), The word 
comprehension refers to "the ability to go beyond the words, to understand the ideas conveyed in the entire text".

Neverthless, based on the previous observation result at grade VIII SMPN 4 Kota Bengkulu, the researcher found some obstacles existing. The first obstacles, students still can not understand the text properly and less motivation to read text, so it is difficult to determine the meaning with only once reading. Then, the students are often out of focus or concentration when they are reading a text, so it is still difficult to determine the meaning of the text and the main idea of a text. For the rest obstacle, the students often get hard to find out the answer of the questions given after reading the text. Thus, these obstacles must be solved since reading is one of important skill to gain the students knowledge.

One way to resolve these obstacles is the teacher must seek reading strategy which is suitable to make teaching and learning become more effective. However it is exactly what encourages teachers to seek an accurate strategy and develop it to the fullest in order to improve students' reading comprehension. There are some strategies and methods in teaching reading especially for junior high school level students namely; POSSE, PQRST, REAP, THIEVES, CORI strategy, and etc. In this research, CORI (ConceptOriented Reading Instruction) strategy used to help the teacher to solve the obstacles in reading. It is because Concept-Oriented Reading Instruction (CORI) is a reading comprehension instructional program that can involve students in reading, understand the text better, and motivate students to read.

\section{LITERATURE REVIEW}

Reading is one of the important skills for all of educational level, including junior high school level. Through reading students can get new ideas, obtain needed information, can support for their ideas, help to complete their assignments and additional their motivation to know all of the world.Not only as an important skill for the student in their life but also as an important aspect in the national final exam. Many of students know about reading benefit but for many students, reading is a tedious job, especially in English reading because they are consider that English is complicated. They are cannot understand the meaning of the text. The awareness of English as foreign language in Indonesia makes them feel hard in study English.

The definitions of reading are variously stated by some experts. Reading comprehension is a foundation to students' overall academic success in school (Alvermann\& Earle, 2003; Guthrie, 2004; OECD, 2009; Zywica\& Gomez, 2008). According to McNamara (2007:3) reading is an extraordinary achievement when one considers the number of levels and components that must be mastered. Reading comprehension becomes especially important in the later elementary grades (Sweet \& Snow, 2003) and provides the basis for a substantial amount of learning in secondary school (Kirsch et al., 2002). Without reading comprehension skill and the motivation for reading to learn, students' academic progress is limited (Alvermann\& Earle, 2003). Readers who 
are metacognitively aware are able to monitor their understanding while reading, developing and monitoring within their strategy repertoires to address any gaps when deriving meaning from text, thus facilitating comprehension (Hong-Nam \&Leavell, 2011).

\section{Definition of Reading Comprehension} Comprehension is $\quad a$ developmental skill in describing idea beginning at the word level and proceeding to attaching meaning to an entire reading selection (Kintsch, Rawson, Snowling, and Hulme, 2005). According to Seyed et al (2010), the word comprehension refers to "the ability to go beyond the words, to understand the ideas conveyed in the entire text", beside that according to (Woolley. G., 2011), Reading comprehension is the process of extracting meaning from text. The goal, therefore, is to gain an overall understanding of what is described in the text rather than to obtain meaning from isolated words or sentences. The Purpose of Reading Comprehension

\section{Kinds of Reading}

Brown (2001: 312) states that there are two types of classroom reading performance, those are oral and silent reading. Oral reading is preferred to the beginning level. At the beginning and intermediate level, oral reading can serve as an evaluative check on processing skills, double as pronunciation check, and serve to add some extra students' participation while silent reading is better to the advance one. Silent reading can be subcategorized into intensive and extensive reading.
According to Brown (2001: 312313), intensive reading is usually a classroom oriented activity in which students focus on the linguistics or semantics details of passage. Intensive reading call students' attention to grammatical forms, discourse markers, and other surface structure details for the purpose of understanding literal meaning, implications and rhetorical relationship, while extensive reading is carried out to achieve a general understanding of a usually somewhat longer text. In the other word extensive reading applies to texts of more than a page, up to and including professional articles, essays, technical reports, short stories, and books. Most extensive reading is performed outside of class time.

3. Teaching Reading Comprehension

In reading strategy there are namely predicting, skimming, scanning, inferring, guessing of new words, self monitoring.

a. Predicting

Predicting means predicts what is in the text, predicting involves thinking about what might happen next in the text. Predicting applied by the reader by using images, title text, as well as the personal experiences of the reader, but to determine whether the reader correctly predicting the use of text and reader confirm or disprove predictions to support the text.

b. Skimming

Skimming is one way the reader for quick reading which aims to get an overview or general idea and the essence of a text. Used skimming readers who want to get a specific information in a manner that does not skip reading sought. in skimming techniques: Use of quick 
glance through the pages, pay attention to the title, read the opening sentence and the conclusion, read the first and last sentence of the paragraph to find the main idea

c. Scanning

Scanning is a technique to reading quickly by scanning information in the search without reading the entire text. This technique often used when the reader just want to find information specific to a quick reading without seeing or reading all the contents of the text, usually by looking at the title of the text, table of contents and so on. Most readers know about the information or answers that will be search, so the reader will be concentrate on specific answer. In this way, we can say that scanning is reading quickly intervening to locate specific information (Test Association Word Wise, 2006).

d. Inferencing

Prezler(2006) said that "inferences are evidence -based guesses i.e. in case of reading; students use their prior knowledge to make inferences about the text"). Inferences are often referred to as what you "read between the lines" that means the author wants the reader to make the jump to the same conclusion the author has made. The inferences are the conclusions that a reader draws about the unsaid passage based on what is actually said by the author.

e. Guessing The Meaning of New Words

One of the most difficult problems that make an obstacle for students in the comprehension of reading is unfamiliar/new words or lack vocabulary. The ability to guess meaning from context is a useful skill to practice and try to improve. There are many things that could help students such as: (1) Guess the meaning of the text which surrounds it (2) The way the word is formed (3) Background knowledge of the students about the subject.

\section{f. Self Monitoring}

A student must take responsibility for their own behavior and able to make changes, then these students have done one step to self-monitor Reviews their performance. Self-monitor also serves as the academic and behavioral assessment of students in improving their academic performance and behavior towards the better.

g. Summarizing

$$
\text { Oxford (2006) defines }
$$

"summarizing as a short description of the main ideas or points of something without any details. Tips for teaching comprehension strategy: Making connections, learners make personal connections from the text with: something in their own life (text to self), another text (text to text), something occurring in the world (text to world). (2) Predicting, Learners use information from graphics, text and experiences to anticipate what will be read/ viewed/heard and to actively adjust comprehension while reading/viewing/listening.

Questioning, Learners pose and answer questions that clarify meaning and promote deeper understanding of the text. (4) Monitoring, learners stop and think about the text and know what to do when meaning is disrupted.(5) Visualising, Learners create a mental image from a text read/viewed/heard. (6) Summarising, learners identify and accumulate the most 
important ideas and restate them in their own words.

CORI is one of strategies that can lead the students reading comprehension. It is suggested by Guthrie (2004) as an instructional strategy, CORI strategy helps students to cope their problem in reading comprehension. ConceptOriented Reading Instruction is a reading comprehension instructional program for grades 3-9 that integrates reading and science through activities and the use of science books during reading instruction. The program supplements a school's standard science and reading curricula and offers instruction in reading strategies, scientific concepts, and inquiry skills. Concept-Oriented Reading Instruction intends to improve reading comprehension and increase reading engagement. The program aims to improve comprehension by teaching students the following strategies that they can use to better understand text they are reading (documented in the National Reading Panel Report, 2005): (1) activating background knowledge, (2) questioning, (3) searching for information, (4) summarizing, (5) organizing graphically, and (6) identifying story structure. The program aims to increase student engagement in reading through five practices: (1) using content-area goals for a conceptual theme during reading instruction, (2) giving students choices and control over their reading topics, (3) providing hands-on activities, (4) using interesting texts for instruction, and (5) organizing opportunities for students to collaborate and learn from text

There are three steps of CORI, each steps of CORI strategy improves the effectiveness of teaching and learning process which is also aimed to improve the students' reading comprehension. First, perceiving text structure, this makes the student to identify the text structure of descriptive texts. Second, inferencing, when the students read the text, they just focused on answering the question given. In inferencing the students try to analyze the words in the texts and make inference on the content of the story. Third, concept mapping, this activity asks the students to recall all the specific information about the text by mapping the concept according to the feature of the texts.

The purpose of CORI strategy is to help students become active readers, make them focus on the text, attract their motivation, have a long-term memory in comprehending the text and increase their score on the test.

According to Guthrie (2007), CORI has some goals. Firstly, CORI's primary aim is to increase students' reading comprehension by increasing their reading engagement. Secondly, the reading goals include the following comprehension strategies: understanding the main idea, making inferences, monitoring comprehension, and using fix-up strategies for information and narrative texts. We included oral reading fluency and vocabulary as enabling competencies. Thirdly, CORI goal is to increase students' knowledge of life science in the domain of environmental science. CORI also includes instruction in the science processes of observation and experimentation. Fourthly, CORI's goal is to increase students' motivation to read, with an emphasis on intrinsic motivation, self-efficacy, perceived 
autonomy, social interaction, and mastery goals in reading.

\section{METHOD}

Experimental research method is a method of research that aims to find whether there is influence to a certain treatment to another by conditioning the desired situation. Quasi-experimental designs identify a comparison group that is as similar as possible to the treatment group in terms of baseline (preintervention) characteristics. The comparison group captures what would have been the outcomes if the programme/policy had not been implemented (i.e., the counterfactual). Hence, the programme or policy can be said to have caused any difference in outcomes between the treatment and comparison groups. (Sugiyono: 2013).

According to Hatch and Farhady (1982), a quasi experimental design is a practical agreement between true experimental and the nature of human language behavior. Porte (2002) also explains that quasi experimental design is appropriate for educational study since many studies of that field usually involved the use of classes that have already been assigned before. Hatch and Farhady (1982) also state that pre-test and post-test are of used in classroom experiments when experimental and control groups are naturally assembled groups.

Table 1

\section{Randomized Group, Pre-Test and Post-Test}

\begin{tabular}{|c|c|c|c|}
\hline Grou & Pre & Independe & Post \\
p & - & nt Variable & -test \\
\hline
\end{tabular}

\begin{tabular}{|c|c|c|c|}
\hline $\mathrm{E}$ & $\mathrm{Y} 1$ & $\mathrm{X} 1$ & $\mathrm{Y} 2$ \\
& $\mathrm{Y} 1$ & $\mathrm{O}$ & $\mathrm{Y} 2$ \\
\hline
\end{tabular}

Notes :

$\mathrm{E} \quad=$ Experiment

group

$\mathrm{C}=$ Control group

$\mathrm{Y} 1=$ Pre-Test

$\mathrm{X} 1=$ Treatment on

the experiment

group using

CORI strategy

$\mathrm{X} 2=$ Treatment on

the control group

Y2 = Post-Test

In this research, the population on the research included all the Eight grade students of the SMPN 4 Bengkulu in Academic Year 2016. There were 25 students for each class.

The sample of this research was decided based on the students pre-test. There were two classes that will be the sample of this research. One class was as experimental group and another class was as control group.

Instrument on this research was reading test. Reading test aimed to measure students' reading comprehension. The researcher used multiple choice forms (A B C D options).There were thirty numbers.

The procedure of this research consisted of three steps, pre-test, treatment, and post-test. It explained more as below,

1. Pre-test

The research gave a pre-test to the students before giving an action or treatment, The purpose of the pre-test to know the students reading ability before treatment.

2. Treatment 
Treatment was given through CORI Strategy for at least 6 meetings. In treatment group the research give steps in CORI Strategy : Perceiving text structure, Inferencing, and concept mapping. This activity asks the students to recall all the specific information about the text by mapping the concept according to the feature of the texts. Control Group

Treatment in the control group was different from experiment group. In experiment group the research should be do : The teacher gave reading text to the students (descriptive text), Students read the text to comprehend the text, the students find the new word and the teacher help the students, students answered the question based on the text, and the teacher correction and valuated the students answer.

3. Post-test

The post-test had given after the treatment to the students. Post-test was given at the end of the treatment to know the improving reading comprehension ability at two classes.

\section{FINDING AND DISCUSSION}

\section{Results of Normality Test}

a. Pre-test Reading Normality Test

The normality test in this research use Kolmogorov-Smirnov method is SPSS v.16 for windows with criteria $\rho>$ 0.05 . The steps are analyze - descriptive statistics - explore. Based on the output of calculation, the significance of normality pre-test score in experimental and control class is 0.52 . It can be concluded that the data are normally distributed because $0.052>0.05$. It means that the distribution of the data is normal. b. Post-test Reading Normality Test
Based on the output of calculation, the significance of normality post-test score in experiment and control class are 0.156 . It can be concluded that the data are normally distributed because $0.156>0.05$. Therefore, the data are normally distributed because $0.156>$ 0.05 . It means that the distribution of the data is normal.

\section{Results of Homogeneity Test}

a. Pre-test Reading Homogeneity Test

Based on the calculation of normality, the researcher got the result that all data in pre-test both experimental class and control class have been distributed normally. The next step of the calculation was finding the pre-test and post-test homogeneity of the data by using SPSS v.16 for windows, specifically by using KolmogorovSmirnov method. The steps are analyze compare means - one way anova.

The output of calculation shows that the significance of pre-test homogeneity result between experimental class and control class is 0.987 . It can be concluded that there is no significant difference between experimental class and control class because 0.987>0.05.

b. Post-test Reading Homogeneity Test

Based on the calculation of normality, the researcher got the result that all data in post-test both experimental class and control class have been distributed normally. The next step of the calculation was finding the pre-test and post-test homogeneity of the data by using SPSS v.16 for windows, specifically by using KolmogorovSmirnov method. The steps are analyze compare means - one way anova.

The output calculation shows that the significance of post-test homogeneity 
result between experimental class and control class is 0.417 . It can be concluded that there is not significant difference between experimental class and control class because $0.417>0.05$.

\section{The Effect of Concept} Oriented Reading Instruction (CORI) Strategy toward Students' Reading Comprehension

Calculation showed that there is significance difference between students' reading comprehension in control class and experiment class before and after treatment. The hypotheses for research question are as follow:

Hypotheses

$$
\begin{aligned}
\mathrm{H}_{0}= & \text { There is no a significant } \\
& \text { difference between group } \\
& \text { means with respect to } \\
& \text { reading comprehension. } \\
\mathrm{H}_{1}= & \text { There is a significant } \\
& \text { difference between group } \\
& \text { means with respect to } \\
& \text { reading comprehension. }
\end{aligned}
$$

The pre- test and post-test result can be seen on the following table:

Table 2

Pre test and post test score

\begin{tabular}{|c|c|c|c|c|c|}
\hline 10 & H & $\mathbf{7 5}$ & $\mathbf{8 0}$ & HF & $\mathbf{7 0}$ \\
\hline 11 & J & $\mathbf{8 5}$ & $\mathbf{7 0}$ & HS & $\mathbf{7 5}$ \\
\hline 12 & LL & $\mathbf{8 0}$ & $\mathbf{8 0}$ & IP & $\mathbf{4 0}$ \\
\hline 13 & MA & $\mathbf{4 0}$ & $\mathbf{7 0}$ & LP & $\mathbf{7 5}$ \\
\hline 14 & MM & $\mathbf{6 5}$ & $\mathbf{6 5}$ & L & $\mathbf{7 0}$ \\
\hline 15 & NA & $\mathbf{4 5}$ & $\mathbf{7 5}$ & LL & $\mathbf{4 5}$ \\
\hline 16 & RI & $\mathbf{6 0}$ & $\mathbf{6 5}$ & MYK & $\mathbf{5 0}$ \\
\hline 17 & RA & $\mathbf{5 5}$ & $\mathbf{6 5}$ & MR & $\mathbf{6 0}$ \\
\hline 18 & RHH & $\mathbf{4 0}$ & $\mathbf{9 0}$ & PS & $\mathbf{6 5}$ \\
\hline 19 & SDA & $\mathbf{6 0}$ & $\mathbf{7 5}$ & RDS & $\mathbf{7 0}$ \\
\hline 20 & TN & $\mathbf{7 0}$ & $\mathbf{9 0}$ & RU & $\mathbf{8 5}$ \\
\hline 21 & WM & $\mathbf{5 5}$ & $\mathbf{8 0}$ & RA & $\mathbf{6 0}$ \\
\hline & & & & RWH & \\
22 & WN & $\mathbf{7 5}$ & $\mathbf{7 5}$ & R & $\mathbf{5 0}$ \\
\hline 23 & YEP & $\mathbf{6 0}$ & $\mathbf{6 5}$ & RDA & $\mathbf{6 5}$ \\
\hline 24 & YZ & $\mathbf{7 0}$ & $\mathbf{6 0}$ & UJ & $\mathbf{5 5}$ \\
\hline
\end{tabular}

An analysis of pre-test and post test score can be seen on the following table:

Table 3

Analysis for Reading Comprehension

\begin{tabular}{|l|l|l|l|c|c|l|}
\hline \multirow{2}{*}{ No } & Test & Group & Mean & $\mathrm{T}$ & Sig & Comp \\
\hline \multirow{2}{*}{1} & Pre & Exp & 64.79 & 0.432 & 0.668 & $\mathrm{P}>0.05$ \\
\cline { 2 - 4 } & & Control & 63.00 & & & \\
\hline & & & & & & \\
\hline 2 & Post & Exp & 80.41 & 3.525 & 0.001 & $\mathrm{P}<0.05$ \\
\cline { 2 - 4 } & & & & & \\
\hline
\end{tabular}

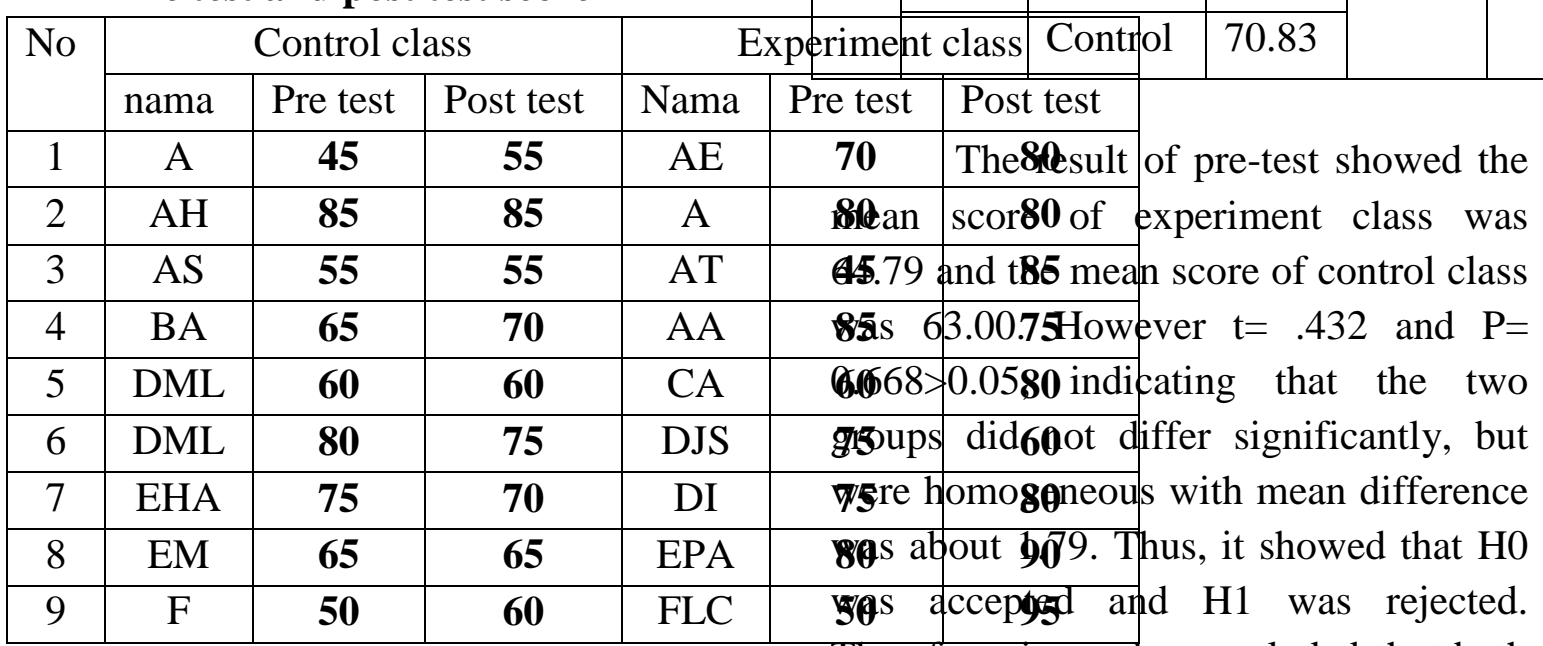

Therefore, it can be concluded that both 
groups were homogenous at the outset of the study.

Furthermore, the result of post test showed the mean of experiment class was 80.41 and the mean of control class was 70.83. However $\mathrm{t}=3.525$ and $\mathrm{P}=$ $0.01<0.05$, indicating that the two groups differ significantly. So the null hypotheses stating that no significant difference existed in the reading score was rejected. Thus, after treatment both groups had difference in ability. In other words CORI strategy is effective for teaching and learning whole reading comprehension.

This research was done in six meetings. In the first meeting the researcher gave reading pre-test to the students. Then the researcher explained about what descriptive text and asked the students to read the text. After that the researcher used CORI strategy as a strategy to help the students in reading comprehension. While doing the research, the students interested with using CORI strategy. Furthermore, in the treatment process the researcher divided the students into five groups then they identified the text structure of descriptive texts. And the next the students analyzed the words in the texts and make inference on the content of the story. After that the teacher asked the students to recall all the specific information about the text by mapping the concept according to the feature of the texts.

Moreover, the use of CORI strategy created a positive atmosphere in the class. CORI strategy helped the students to be active readers, made them focus on the text, attracted their motivation, improved their long-term memory in comprehending the text and increased their score on the post test.

CORI is one of strategies that can lead the students reading comprehension. It is suggested by Guthrie (2004). As an instructional strategy, CORI strategy helps students to cope their problem in reading comprehension.

Concept Oriented Reading Instruction intends to improve reading comprehension and increase reading engagement. The program aims to improve comprehension by teaching students the following strategies that they can use to better understand text they are reading (documented in the National Reading Panel Report, 2005): (1) activating background knowledge, (2) questioning, (3) searching for information, (4) summarizing, (5) organizing graphically, and (6) identifying story structure. The program aims to increase student engagement in reading through five practices: (1) using content-area goals for a conceptual theme during reading instruction, (2) giving student choices and control over their reading topics, (3) providing hands-on activities, (4) using interesting texts for instruction, and (5) organizing opportunities for students to collaborate and learn from text

However, this research also gives produces a similar result to another relevant previous studies. This research and the previous researchers proved that CORI strategy was able to increase the students' reading comprehension and motivation. The first was Azis (2015) at the SMP level in Siak. The result of research showed that the use of CORI strategy improved the effectiveness of teaching and learning process. The 
second was Nailatun (2014) at the SMP level in Central Java. She found there was a significant difference on reading comprehension before and after being taught by using CORI. The third was Saraswati (2013), who compared CORI and DI at the SMK level in Sampit. The result of her research showed that (1) The teacher is suggested to implement CORI to teach reading manual text in order that thestudents reading comprehension ability is better; (2) CORI is suitable for students having high reading interest, whereas DI(Differentiated Instruction) is for those who have low reading interest; and (3) The other researchers can also develop the methods used in this research as a way of making revision to the weaknesses of this research.

In addition, the result by lndah (2011) at the University level in Medan was also similar to this research. It showed that (1) Both Concept Oriented Reading Instruction (CORI) and Strategic Instruction Model (SIM) significantly affect students' reading comprehension achievement;(2) Self efficacy has a significant effect on students' reading comprehension achievement; and (3) there is a significant interaction between reading instructions and self efficacy on students' reading comprehension achievement.

\section{CONCLUSION}

It found that CORI strategy was effective to improve students' reading comprehension. The use of CORI

\section{REFERENCES}

Abdullah Azis. (2015). The use of Concept-Oriented Reading Instruction (CORI) to improve teaching and learning of reading strategy created a positive atmosphere in the class. CORI strategy helped the students to be active readers, made them focus on the text, attracted their motivation, improved their long-term memory in comprehending the text and increased their score on the post test. Based on the conclusion, the researcher would like to give some suggestions related to this research. Firstly, English teachers need to stimulate students to be active in the teaching and challenge them to read more effectively in teaching and learning process. Based on the reason, the language teachers should choose a certain teaching method or strategy that can build a good atmosphere of teaching learning process such as using CORI strategy. Secondly, student needs great motivation. With a great motivation, they will practice more in order to explore their English. They also should practice the reading comprehension more, because it can give more knowledge for them. CORI strategy is an effective strategy that can be used to improve students' reading comprehension and to make the students be an active reader. Thirdly, it is better for further researcher to conduct a study in the SMP level with different methodology, such as action research. Besides, probably the results will get better if the study conducted in other schools which have better language facility such as modern laboratory. Then it would be better for further research on other aspects of reading comprehension. narrative texts to grade VIII-B students of SMP Islamic Center Siak. Journal English Language Teaching (ELT) Volume 1 Nomor 1, Maret 2015 
Brown, H. D. (2001). Teaching by principles: An interactive approach to language pedagogy Second Edition. New York: Pearson EducationCompany.

Duke, N. (2003, March 7). Comprehension instruction for informational text.Presentation at the annual meeting of the Michigan Reading Association, Grand Rapids, MI.

Alvermann, D., \& Earle, J. (2003).Comprehension instruction.In A. P. Sweet \& C. Snow (Eds.), Rethinking reading comprehension (pp. 12-30). New York: Guilford Press.

Guthrie, J. T., Wigfield, A., Barbosa, P., Perencevich, K. C., Taboada, A., Davis, M. H., Et Al. (2004). Increasing reading comprehension and engagement through concept-oriented reading instruction.Journal

OfEducational Psychology, 96, 403-423.Retrived on November 07th 2016.

Guthrie, J. T. (2007). Increasing reading comprehension and engagement through concept-oriented reading instruction. Journal OfEducational Psychology, 96, 403423. Retrived on November 07th 2016.

Hatch and Farhady.(1982). Research design and statistics for applied linguistics.Introduction, Newbury House. ISBN 0-88377-202-7.
Indah, D. (2011). A Comparative Study of Concept Oriented Reading Instruction (CORI) and Strategic Instruction Model (SIM) to affect students' reading comprehension achievement Journal English Language Teaching (ELT) Volume 1 Nomor 1, Maret 2015

Kintsch, W., Rawson, K. A., Snowling, M. J., AndHulme, C. (2005). Comprehension. Malden: Blackwell.

Kirsch, I., de Jong, J., LaFontaine, D., McQueen, J., Mendelovits, J., \&Monseur, C. (2002).Reading for change: Performance and engagementacross countries. Paris: Organisation for Economic Co-operation and Development

Mcnamara, S. Daniel. (2007). Reading comprehension strategy. NewnYork: Taylor\& Francis Group, LLC

Nailatun, J. (2014). The effect of the use of Concept-Oriented Reading Instruction (CORI) to improve teaching and learning of reading narrative texts to the eighth grade students of SMP Ma'arifTegalSambiJepara in academic year 2013/2014. Journal English Language Teaching (ELT) Volume 1 Nomor 1, Maret 2015

National Reading Panel Report.(2005). Students' reading result.Newyork.

OECD. (2009). Reading for comprehending. Santa Monica, 
CA: Office of Education Research and Improvement.

Oxford. (2006). Word power dictionary( $\mathrm{Pp}$ 717). New York: Oxford University Press.

Prezler, J. (2006). Strategies to help readers make meaning through inferences grade 4 12. (Pp 4).South Dakota Department of Education.

RAND Reading Study Group. (2002). Reading for understanding: Toward a research and development program in reading comprehension. Santa Monica, CA: Office of Education Research and Improvement.

Saraswati. (2013). The use of CORI strategy to improve students' interest in reading acivity. Journal English Language Teaching (ELT) Volume 1 Nomor 1, Maret 2015

SeyedHosseinFazeli, M. E. (2010). Language In India:Some Gaps In The Current Studies Of Reading
In Second/Foreign Language Learning. (Vol.10).Issue4.(Pp376380).

Sweet, A. P., \& Snow, C. E. (2003).Rethinking reading comprehension. New York: Guilford Press.

TestAssociation Word Wise.(2006). Strategies to help readers make meaning through inferences grade 4 12. (Pp 4).South Dakota Department Of Education.

Woolley. G. (2011). Reading Comprehension: Assisting Children With Learning Difficulties. Retrieved From Http://Www.Springer.Com/Cda/C ontent/Document/Cda_Download document/9789400711730C1.Pdf?SGWID=0-0-451158048-P174102871.

Zywica Gomez. (2008). The practice of social research. Cape Town: Oxford University Press Southern Africa. 